\title{
Seroprevalence rates of Toxoplasma gondii, Rubella, Cytomegalovirus among first trimester pregnant women in Istanbul
}

\author{
Aysegul Ozel ${ }^{1}$, Mujde Canday ${ }^{1}$, Aslihan Yurtkal ${ }^{1}$, Ebru Alici Davutoglu' ${ }^{1}$, Yasam Kemal \\ Akpak $^{2}$, Dogay Nurtac Ozmus ${ }^{2 *}$, Alper Ileri ${ }^{2}$, Adnak Budak ${ }^{2}$, Riza Madazli ${ }^{1}$
}

\begin{abstract}
${ }^{1}$ Department of Obstetrics and Gynaecology, Istanbul University, Cerrahpasa Medical Faculty Istanbul, Turkey
${ }^{2}$ Department of Obstetrics and Gynaecology, Tepecik Training and Research Hospital, Izmir, Turkey
\end{abstract}

Received: 27 October 2020

Accepted: 04 December 2020

*Correspondence:

Dr. Dogay Nurtac OZMUS,

E-mail: dogay.ozmus@hotmail.com

Copyright: (c) the author(s), publisher and licensee Medip Academy. This is an open-access article distributed under the terms of the Creative Commons Attribution Non-Commercial License, which permits unrestricted non-commercial use, distribution, and reproduction in any medium, provided the original work is properly cited.

\begin{abstract}
Background: Toxoplasma Gondii, Rubella, and Cytomegalovirus (CMV) are the most common causes of congenital infections worldwide. There is not a consensus on these infectious agents should be screened during pregnancy. The aim of this study is to determine the prevalence of toxoplasma, rubella, and CMV infections in order to know the need for antenatal screening.

Methods: This retrospective cross-sectional study was performed on 1309 ambulatory pregnant patients who applied to the obstetric clinic of a university hospital between October 2016 and April 2018. Documents of patients in the first trimester were reviewed and serologic data of Toxoplasma gondii, CMV, Rubella infections were retrieved from the computer database.

Results: Of 1309 pregnant women, positivity for anti-Toxoplasma IgG antibody was 352(26.9\%), while 17(1.3\%) of the subjects tested were positive for the anti-Toxoplasma IgM antibody. These positivities of the pregnant women for anti-Rubella IgG and IgM were $1147(87.6 \%)$ and (0.1\%), respectively. These positivities of the pregnant women for anti-CMV IgG and IgM were $1163(88.8 \%)$ and $17(1.3 \%)$, respectively.

Conclusions: We detected high rates of immunity against Rubella and CMV but low rates of immunity against Toxoplasma in this retrospective cohort of pregnant women. Due to high rates of seropositivity against Rubella and $\mathrm{CMV}$, routine nationwide screening may not be necessary.
\end{abstract}

Keywords: Cytomegalovirus, Maternal infection, Prenatal infection, Rubella, Toxoplasma

\section{INTRODUCTION}

There are some infectious agents which can complicate both mother and fetus during pregnancy. Toxoplasma gondii, Rubella, and Cytomegalovirus (CMV) are among the most common causes of congenital infections worldwide. ${ }^{1}$ Toxoplasma gondii is a kind of intracellular parasitic protozoa that may cause congenital toxoplasmosis when transmitted to a fetus transplacentally. ${ }^{2}$ Congenital toxoplasmosis may be either asymptomatic or symptomatic with the association of various clinical manifestations such as intrauterine fetal loss, hearing loss, chorioretinitis, hydrocephalus, microcephaly, and seizures. ${ }^{3}$ Rubella is an infectious agent that infected people by inhalation of infected particle and belongs the RNA virus family. Congenital rubella syndrome can result in miscarriage, sensorineural hearing loss, ocular defects, including cataracts, glaucoma, retinopathy, and microphthalmia, various heart defects, and mental retardation. ${ }^{3}$ In perinatal period, CMV is the most common viral infection and leads to congetinal CMV infection. Congenital CMV infection is the most common reason for non-hereditary hearing loss 
in the world besides also can cause microcephaly, chorioretinitis, seizures, growth restriction. ${ }^{4}$

There is no consensus on whether it is necessary to screen for infectious agenst during the pregnancy. The seropositivity rates of the population should be known for deciding to routine screening of these infections in the population. In this study, we aimed to investigate the seroprevalence of Toxoplasma, Rubella, and CMV infections through antenatal screening.

\section{METHODS}

This study was performed on 1309 ambulatory pregnant patients who applied to the obstetric clinic of a university hospital between October 2016 and April 2018. Documents of patients in the first trimester were retrospectively reviewed and serologic data of Toxoplasma gondii, CMV, Rubella infections were retrieved from the computer database. The study was approved by the local ethics committee and was conducted in accordance with the Declaration of Helsinki. Informed consent was obtained from all participants. Toxoplasma gondii, CMV, Rubella IgG, and IgM antibodies were analyzed using an enzyme-linked immunosorbent assay (ELISA) method. All reactive samples were repeated in duplicate for $\operatorname{IgM}$ tests and accepted as positive.

\section{Statistical analysis}

Statistical Package for Social Sciences version 17.0 (SPSS Inc., Chicago, IL, USA) software was used for calculating descriptive statistics. Data were presented as mean \pm standard deviation. Categorical variables were presented as frequencies and/or percentages.

\section{RESULTS}

In our study, high rates of immunity against Rubella and CMV but low rates of immunity against toxoplasma was found. The rates of seropositivity show variations on different region of Turkey. The mean age and gestational week of women were $28.3 \pm 5.1$ years and $11.4 \pm 1.5$ weeks, respectively. The rates of seropositivity for Toxoplasma, Rubella, and CMV IgG and IgM are shown in Table 1. After assesment of 1309 pregnant women; 352 (26.9\%) pregnant women had positivity for anti-Toxoplasma IgG antibody, $17(1.3 \%)$ of pregnants were positive for the anti-toxoplasma $\operatorname{IgM}$ antibody, and $10(2.8 \%)$ of pregnants were positive for both anti-Toxoplasma IgG+IgM antibodies. The rates of seropositivities in the pregnant women for anti-rubella $\mathrm{IgG}, \mathrm{IgM}$ and $\mathrm{IgG}+\mathrm{IgM}$ were $1147(87.6 \%), 1(0.1 \%)$ and $1(0.08 \%)$, respectively. The seropositivities of the pregnant women for anti-CMV $\mathrm{IgG}$, IgM, and both $\mathrm{IgG}+\operatorname{IgM}$ were $1163(88.8 \%)$, $17(1.3 \%)$, and $17(1.5 \%)$, respectively.

Table 1: Seroprevalence rates for Toxoplasma gondii, Rubella, CMV in pregnant women.

\begin{tabular}{|lllll|}
\hline $\begin{array}{l}\text { Type of } \\
\text { pathogen }\end{array}$ & $\begin{array}{l}\text { IgM } \\
\text { positive } \\
\mathbf{n}, \%\end{array}$ & $\begin{array}{l}\text { IgG } \\
\text { positive } \\
\mathbf{n}, \%\end{array}$ & $\begin{array}{l}\text { IgG } \\
\text { negative } \\
\mathbf{n}, \%\end{array}$ & $\begin{array}{l}\text { IgM+IgG } \\
\text { positive } \\
\text { n, \% }\end{array}$ \\
\hline $\begin{array}{l}\text { Toxoplasma } \\
\text { gondii }\end{array}$ & $17,1.3$ & $\begin{array}{l}352, \\
26.9\end{array}$ & $\begin{array}{l}737, \\
56.3\end{array}$ & $10,2.8$ \\
\hline Rubella & $1,0.1$ & $\begin{array}{l}1147, \\
87.6\end{array}$ & $23,1.8$ & $1,0.08$ \\
\hline CMV & $17,1.3$ & $\begin{array}{l}1163, \\
88.8\end{array}$ & $2,0.2$ & $17,1.5$ \\
\hline
\end{tabular}

CMV: Cytomegalovirus

\section{DISCUSSION}

Toxoplasma seropositivity rate is associated with sociocultural and nutritional habits, geographic climatic variations, frequency of contact with cats. ${ }^{5}$ There is inverser ratio between risk of fetal transmission and the gestational age, from less than $15 \%$ at 13 weeks of gestation to greater than $70 \%$ at 36 weeks. $^{6}$ Approximately 1.5 cases per 1000 live births has congenital toxoplasmosis. Although $90 \%$ of congenital toxoplasmosis cases remain asymptomatic, whenever a fetal infection is confirmed, treatment should be considered with pyrimethamine sulfadiazine and folinic acid, and spiramycin., ${ }^{7,3}$

Table 2: Results of studies evaluating toxoplasma, rubella, CMV seropositivities in the Istanbul region.

\begin{tabular}{|c|c|c|c|c|c|c|c|}
\hline Authors & Interval & $\begin{array}{l}\text { Toxoplasma } \\
\text { IgM }(\%)\end{array}$ & $\begin{array}{l}\text { Toxoplasma } \\
\text { IgG }(\%)\end{array}$ & $\begin{array}{l}\text { Rubella IgM } \\
(\%)\end{array}$ & $\begin{array}{l}\text { Rubella } \\
\text { IgG }(\%)\end{array}$ & $\begin{array}{l}\text { CMV } \\
\operatorname{IgM}(\%)\end{array}$ & $\begin{array}{l}\text { CMV } \\
\text { IgG }(\%)\end{array}$ \\
\hline Dogan et al ${ }^{14}$ & $2008-2013$ & 0.8 & 31.4 & 0.2 & 95.7 & 0.8 & 99.3 \\
\hline Karacan et al $^{15}$ & 2009-2013 & 0.4 & 23.1 & 0.5 & 95 & 0.4 & 84 \\
\hline Keskin et al $^{16}$ & 2011-2013 & 0.9 & 31.2 & 0.1 & 95.7 & 0.7 & 99.3 \\
\hline Numan et al ${ }^{17}$ & $2013-2015$ & 0 & 31 & 0.2 & 94.2 & 0.5 & 99.5 \\
\hline Present study & 2016-2018 & 1.3 & 26.9 & 0.1 & 87.6 & 1.3 & 88.3 \\
\hline
\end{tabular}

Pappas et al reviewed the seroprevalence data on pregnancy/childbearing age from different part of the world and reported a range between $10 \%$ and $75 \%$, especially high prevalence exist in Latin America, parts of Eastern/Central Europe, the Middle East, parts of south-east Asia and Africa. ${ }^{8}$ In this study, we found a seropositivity rate of $26.9 \%$ for Toxoplasma gondii. In different regions of Turkey Toxoplasma seropositivity 
rate changes between $18.3 \%$ and $60.4 \%$. While in the southeastern part of Turkey, such as in Sanliurfa, Hatay, Adiyaman, Kahramanmaras, seropositivity rates are $60.4 \%, 52.1 \%, 48.4 \%, 47.1 \%$ respectively, in the western part of Turkey, such as in Usak, this rate is $18.3 \% .^{9-13}$ Toxoplasma seropositivity rates were found $31.4 \%$, $23.1 \%, 31.2 \%, 31 \%$ in other studies which also from Istanbul region (Table 2). ${ }^{14-17}$

Seroprevalence of Toxoplasma was higher in the eastern part of Turkey than in the western parts because the Turkish diet in the eastern part of Turkey consists of large amounts of raw vegetables and undercooked meats. Women especially those who were seronegative during pregnancy, should be educated in nutrition and hygiene habits. However, Mario Di et al reported in their metaanalysis that there is little evidence from randomized controlled trials about the effectiveness of prenatal education for reducing congenital toxoplasmosis even though observational studies suggest it is. ${ }^{18}$

The risk of vertical Rubella transmission is $80-100 \%$ in the first trimester, $10-20 \%$ in the second trimester, and with an increase up to $60 \%$ at term rubella virus causes severe defects in fetus by cellular damage on dividing cells. ${ }^{19}$ Due to high transmission risk in the first trimester from a nonimmune mother, screening of seronegative women before pregnancy is important. Immunization should be offered to these women at the preconceptional period against the Rubella virus. The routine vaccination program was started in 2006 in Turkey by the Ministry of Health and Social Welfare. We found the $87.6 \%$ seropositivity rate for Rubella. Different seropositivity rates were detected in Van $(99.5 \%)$, Hatay (95\%) and, Edirne $(76.6 \%) .{ }^{20,10,21}$ The rates differ $94.2 \%-95.7 \%$ in the Istanbul region (Table 2). Our data belongs to ten years later from the vaccine that was introduced into National Vaccination Calendar. In our study, we detected 23(1.8\%) pregnant women with Rubella seronegativity. These data demonstrated that even national vaccination program has achieved success, we are still able to meet seronegative pregnant women because such women are neither vaccinated nor exposed to the virus. We agree that seronegative women at reproductive age should be screened and vaccinated before pregnancy.

CMV infection is the most common intrauterine infection which causes more severe damage if exposed during the first trimester of pregnancy. ${ }^{4}$ The rate of symptomatic disease in infected neonates at birth is approximately $10 \%, 15 \%$ of the infected neonates develop late sequelae. ${ }^{22}$ We found in this study that $1.3 \%$ CMV IgM positivity rate and $88.8 \% \mathrm{CMV} \mathrm{IgG} \mathrm{positivity} \mathrm{rate} \mathrm{that} \mathrm{is}$ comparable with other results from the Istanbul region (Table 2). These rates were found in $0.1-3.2 \%$ and $80.3-$ $99.8 \%$ in several reports from different regions of Turkey. ${ }^{23}$ The rate of CMV seropositivity varies widely in the world. The rate is higher in findings of our present study than some countries in Europe such as France, Finland $(53.1 \%, 56.3 \%$ respectively) but, lower than Iraq where the seropositivity rate reported as $100 \% .^{24-27}$ And another study which was performed in Turkey, Gun et al found seropositivity of $\operatorname{IgG/IgM}$ antibody for CMV, rubella and toxoplasma gondi that were $73.3 \% / 3.7 \%$, $90 \% / 0.6 \%, 31.5 \% / 2.0 \%$ respectively. ${ }^{28}$ Pregnant women are in a risk group if they have in a close and long-term relationship with children under the age of three. Hygiene rules should be advised to especially seronegative pregnant women in the risk group.

There are several limitations to this study. Retrospective study design and inadequate data about patients' socioeconomic and educational status, dietary habits, and neonatal outcomes in patients with suspected acute infection are among these limitations.

\section{CONCLUSION}

We detected high rates of immunity against Rubella and CMV but low rates of immunity against Toxoplasma in this retrospective cohort of pregnant women in accordance with the results of other studies from Istanbul and different regions of Turkey. This information may enligthen for the argument against routine nationwide screenings for Rubella and CMV infections during pregnancy. Due to cost-effectiveness issues targeted serology should be considered on a case by case basis. Routine screening might be more appropriate only in high-risk groups.

\section{Funding: No funding sources Conflict of interest: None declared}

Ethical approval: The study was approved by the Institutional Ethics Committee (167259 Dated 03.05.2017)

\section{REFERENCES}

1. Vergnano S, Heath PT. Fetal and neonatal infections. Med. 2013;41:723-29.

2. Many A, Koren G. Toxoplasmosis during pregnancy. Can Fam Physician. 2006;52: 29-0.

3. Leeper C, Lutzkanin A. Infections During Pregnancy. Prim Care Clin Office Pract. 2018;45:567-86.

4. Cannon MJ, Davis KF. Washing our hands of the congenital cytomegalovirus disease epidemic. BMC Pub Health. 2005;5:70.

5. Prasoona KR, Srinadh B, Sunitha T, Sujatha M, Deepika MLN, Vijaya Lakshmi B, et al. Seroprevalence and Influence of Torch Infections in High-Risk Pregnant Women: A Large Study from South India. The J Obst Gynecol India. 2015;65:301-09.

6. Kieffer F, Wallon M. Congenital toxoplasmosis. Handb Clin Neurol. 2013;112:1099-101.

7. SYROCOT (Systematic Review on Congenital Toxoplasmosis) study group, Thie baut R, Leproust S, Chene G, Gilbert R. Effectiveness of prenatal treatment for congenital toxoplasmosis: a meta- 
analysis of individual patients' data. Lancet. 2007;369:115-22.

8. Pappas G, Roussos N, Falagas ME. Toxoplasmosis snapshots: global status of Toxoplasma gondii seroprevalence and implications for pregnancy and congenital toxoplasmosis. Int $\mathrm{J}$ Parasitol. 2009;39:1385-94

9. Harma M, Gungen N, Demir N. Toxoplasmosis in pregnant women in Sanluurfa. Southeastern Anatolia City, Turkey. J Egypt Soc Parasitol. 2004;34:51925.

10. Ocak S, Zeteroglu S, Ozer C, Dolapcioglu K, Gungoren A. Seroprevalence of Toxoplasma gondii, rubella and cytomegalovirus among pregnant women in Southern Turkey. Scand J Infect Dis. 2007;39:231-34.

11. Kolgelier S, Demiraslan H, Kataş B, Guler D. Seroprevalence of toxoplasma gondii in pregnant women. Dicle Med J. 2009;36:170-72.

12. Bakacak M, Bostancı MS, Kostu B, Ercan O, Serın S, Avc1 F, et al. Seroprevalence of Toxoplasma gondii, rubella and cytomegalovirus among pregnant women. Dicle Med J. 2014;41:326-31.

13. Toklu DG. Antibodies frequency against toxoplasmosis, rubella virus, and cytomegalovirus in pregnant women. J Clin Anal Med. 2013;4:38-0.

14. Doğan K, Güraslan H, Ozel G, Aydan Z, Yaşar L. Seroprevalence rates of Toxoplasma gondii, rubella, cytomegalovirus, syphilis, and hepatitis B, seroprevalences rate in the pregnant population in Istanbul. Turkiye Parazitol Derg. 2014;38:228-33.

15. Karacan M, Batukan M, Cebi Z, Berberoglugil M, Levent S, Kir M, et al. Screening cytomegalovirus, rubella, and toxoplasma infections in pregnant women with unknown pre-pregnancy serological status. Arch Gynecol Obstet. 2014;290(6):1115-120.

16. Keskin DD, Keskin S. Toxoplasma, Rubella, CMV. $\mathrm{HBV}$, anti-Hbs, HCV, HIV seroprevalence in firsttrimester pregnant women. Selcuk Med J. 2013;29:123-6.

17. Numan O, Vural F, Aka N, Alpay M, Coskun AD. TORCH seroprevalence among patients attending Obstetric Care Clinic of Haydarpasa Training and Research Hospital affiliated to the Association of Istanbul Northern Anatolia Public Hospitals. North Clin Istanb. 2015;2:203-09.

18. Di Mario S, Basevi V, Gagliotti C, Spettoli D, Gori G, D'Amico R, et al. Prenatal education for congenital toxoplasmosis. Coch Data Syst Rev. 2015(10).
19. Neu N, Duchon J, Zachariah P. TORCH infections. Clinics in perinatology. 2015;42(1):77-103.

20. Karakas A, Türker T, Arslan E, Turhan V. Investigation of Rubella susceptibility rate among women of childbearing age in a private medical center, Van province, Turkey. Tür Hij Deney Biyol Dergisi. 2010;67:179-84.

21. Kolgelier S, Demiraslan H, Kataş B, Guler D. Seroprevalence of Toxoplasma gondii in Pregnant Women. Dicle Med J. 2009;36:170-72.

22. Varol FG, Sayin NC, Soysuren S. Seroprevalence of Toxoplasma gondii antibodies in an antenatal population of the Trakya region. J Turk Soc Obstet Gynecol. 2011;8:93-9.

23. Gindes L, Teperberg-Oikawa M, Sherman D, Pardo J, Rahave G. Congenital cytomegalovirus infection following primary maternal infection in the third trimester. BJOG. 2008;115:830-35.

24. Aynioglu A, Aynioglu O, Altunok ES. Seroprevalence of Toxoplasma gondii, rubella and Cytomegalovirus among pregnant females in northwestern Turkey. Acta Clinica Belgica. 2015;70(5):321-4.

25. Picone O, Vauloup-Fellous C, Cordier AG, Parent Du Chátalet, Senat M, Frydman R, et al. A 2- year study on cytomegalovirus infection during pregnancy in a French hospital. BJOG. 2009;116:818-23.

26. Alanen A, Kahala K, Vahlberg T, Koskela P, Vainionpää R. Seroprevalence, the incidence of prenatal infections and reliability of maternal history of varicella-zoster virus, cytomegalovirus, herpes simplex virus and parvovirus B19 infection in SouthWestern Finland. BJOG. 2005;112:50-6.

27. Aljumaili ZKM, Alsamarai AM, Najem WS. Cytomegalovirus seroprevalence in women with bad obstetric history in Kirkuk, Iraq. J Infect Pub Heal. 2014;7:277-88.

28. Gun I, Ertugrul S, Kaya N, Akpak YK. Seroprevalence among Turkish pregnant women. Health MED. 2012;6(7):2471-76.

Cite this article as: Ozel A, Canday M, Yurtkal A, Davutoglu EA, Akpak YK, Ozmus DN, et al. Seroprevalence rates of toxoplasma gondii, rubella, cytomegalovirus among first trimester pregnant women in Istanbul. Int $\mathbf{J}$ Reprod Contracept Obstet Gynecol 2021;10:22-5. 